Original Research Paper

\title{
Sequence Stratigraphic Analysis from Well Logs of an X- Field, Niger Delta, Nigeria
}

\author{
Godwin Omokenu Emujakporue and Alphonsus Joseph Eyo \\ Department of Physics, University of Port Harcourt, Nigeria
}

Article history

Received: 12-01-2016

Revised: 25-06-2016

Accepted: 02-07-2016

Corresponding Author:

Godwin Omokenu

Emujakporue

Department of Physics,

University of Port Harcourt,

Nigeria

Email:godwin.emujakporue@uniport.edu

\begin{abstract}
The sequence stratigraphic analysis of the area was studied using well log information in order to determine the lithostratigraphy, chronostratigraphy, possible reservoir sands, age and depositional environment of the study area for opportunities that will support exploration program. The depositional environment penetrated by the wells interpreted from log signatures gave three major facies association. The blocky and coarsening upward (funnel shape), the blocky and fining upward (bell shape) and the erratic (serrated or spiky) facies representing distributary mouth bar, distributary channel and marine mud facies respectively. The sediment deposition of the coastal deltaic and shallow marine delineated for the wells were inferred from the study. Lowstand Systems Tract (LST), Transgressive Systems Tract (TST) and Highstand Systems Tract are the depositional sequences observed. The Maximum Flooding surfaces observed from the stratigraphy analysis indicate major shale break (high shale content). The study area is dominated by altenation of sand and mudstone lithologies, which occurs in approximate ratio of 60:40. The stratigraphic column of the wells was subdivided into sequence boundary, system tracts and sedimentary cycles based on the integration of the various dataset. Some of the sequences have potential of a source rock and seals. The system tracts have the characteristics of good seal and traps. The Maximum Flooding Surfaces and sequence boundaries observed in the wells are four and five respectively. The depths at which the Maximum Flooding Surface occur are 1300, 9300, 9750 and $7050 \mathrm{ft}$ while the sequence boundaries occurred at the depths of 12150 , $10850,8550,7425$ and $6875 \mathrm{ft}$ respectively.
\end{abstract}

Keywords: Stratigraphic Analysis, Niger Delta, Depositional Environment, Depositional Sequences, Sequence Boundaries, Systems Tracts, Maximum Flooding Surfaces

\section{Introduction}

The Niger Delta is a major hydrocarbon provinces in the world (Petroconsultants, 1996). In West African continental margin, the Niger Delta is very important. Hydrocarbon is mainly produced from sandstones and unconsolidated sands of the Agbada Formation. Niger Delta occupies about $75,000 \mathrm{~km}^{2}$ area in southern part of Nigeria (Whiteman, 1982).

Depositional history of the area is an indication of the basement response to sea-level variation, tectonics activities, sediment supply and climate change (Oyedele et al., 2013). These depositional and environmental factors are responsible for the cycles of sediment and depobelt formed in different parts of the basin. The accumulated sediments during each cycle is known as depositional sequence. The depositional sequence is sub-divided into different system tracts based on their position within the sequence stratigraphy analysis (Embry et al., 2007).

The objective of the study are to carry out sequence stratigraphic interpretation of well logs in order to establish correlation of units and its hydrocarbon potential implication within the study area. The research also involves the determination of environment of deposition, maximum flooding 
surfaces and boundary of sequences from the available well logs.

\section{Geological Settings of the Field}

The study area is within the coastal swamp depobelt in western part of Niger Delta (Fig. 1). Figure 2 is a map of the study area.
The basin is located on the continental margin of the Gulf of Guinea, in southern part of Nigeria. The Niger Delta is within latitudes $3^{0}-6^{0}$ and longitudes $5^{0}$ $8^{0}$. It covers an area of $75,000 \mathrm{~km}^{2}$ with average thickness of about $12 \mathrm{~km}$ (Knox and Omatsola, 1988). It is highly petroliferous and has about five percent of total hydrocarbon reserves in the world.

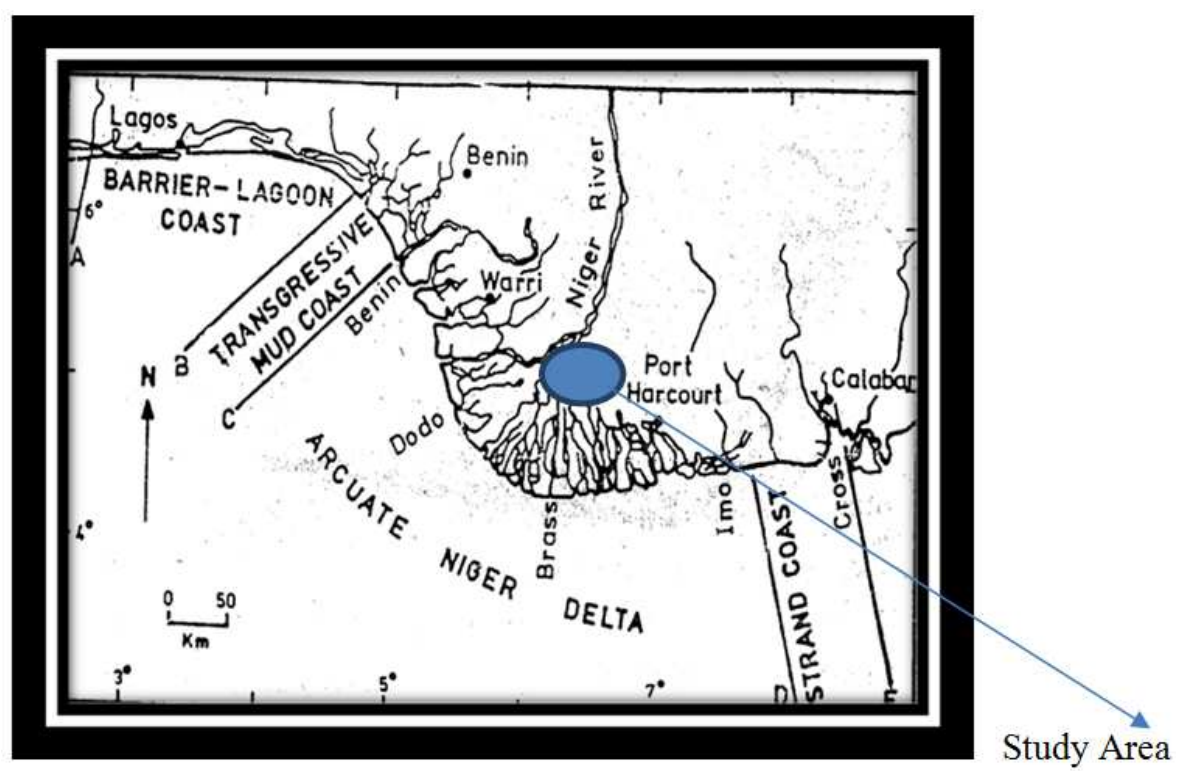

Fig. 1. Niger delta map indicating studied area

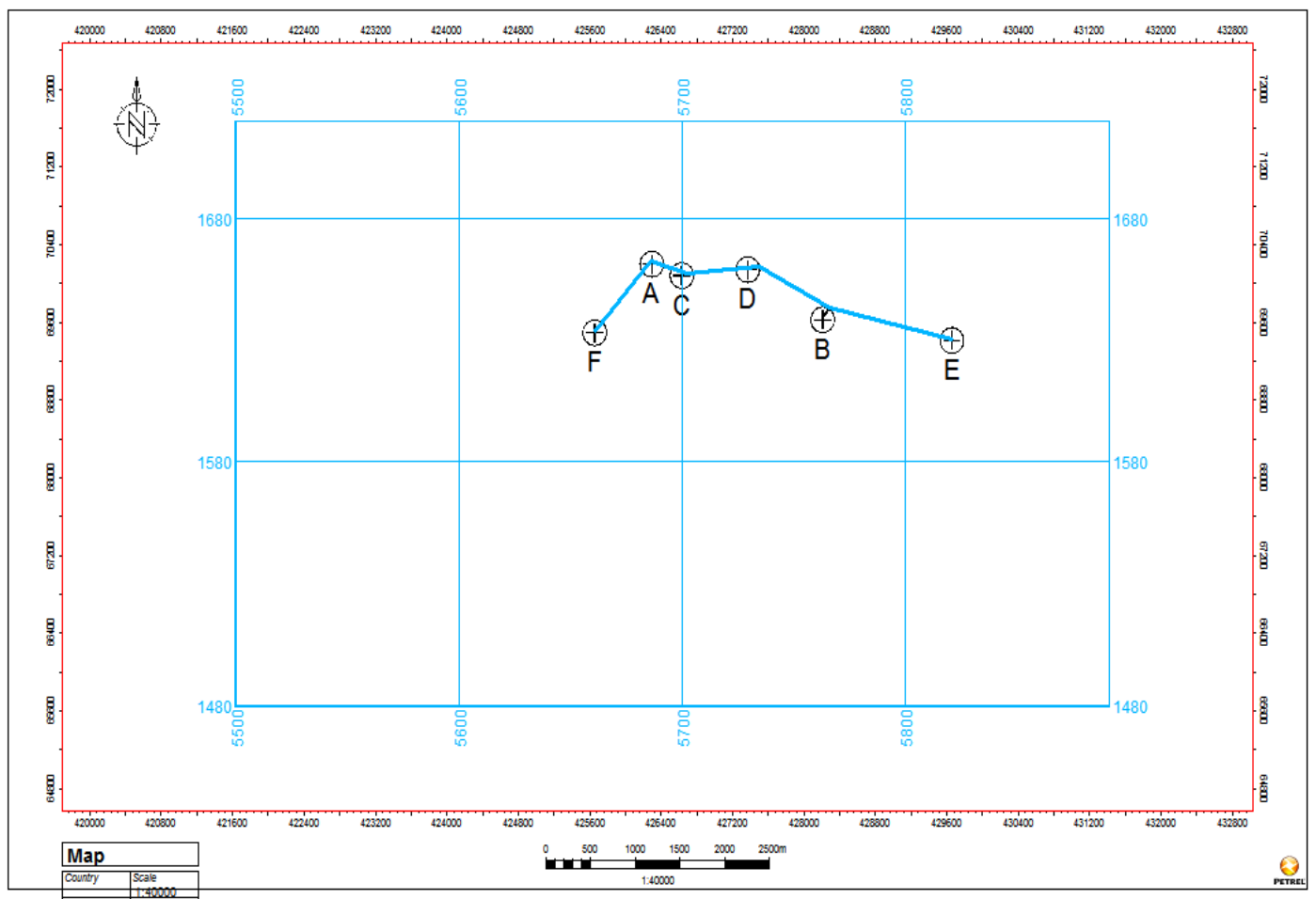

Fig. 2. The X-field base map 
The basin has one petroleum system known as the Tertiary Niger Delta petroleum system (Orife and Avbovbo, 1994; Ekweozor and Daukoru, 1994; Reijers et al., 1997; Tuttle et al., 1999).

There are three major stratigraphic units in the Niger Delta. The age of the stratigraphy is between Eocene and Recent. These units are the Akata, Agbada and Benin Formations. The basal Akata Formation is made up of at least $6,500 \mathrm{~m}$ of marine shale (Ola-Buraimo et al., 2010). Agbada Formation which overlies the basal Formation is a deposits of paralic, coastal and fluvial marine. It is an alternation of sandstones and mudstone. The topmost Benin Formation contains backswamp, sands and gravel. Benin Formation is approximately $2,500 \mathrm{~m}$ thick.

\section{Materials and Methods}

Suite of well logs obtained from six wells were used for the study. Each suite of log comprises of gamma-ray, resistivity and formation density logs. The approach adopted for the study is shown in Fig. 3.

\section{Data Editing, Correction and Import}

Quality control was applied to the data. Thereafter, ASCII data importation and loading into Schlumberger Petrel software 2009. $1^{\mathrm{TM}}$ platform were done. It is from here that well log correlations were loop-tied to assure consistency.

\section{Determination of Lithology and Reservoir}

Gamma ray log was used for lithology identification. It measured the natural radioactivity component of the formation in API value. The scale of the gamma ray log ranges between 0-150 API. High API values indicate shale while low value is sand. Deflections of the gamma ray $\log$ to the right and left is interpreted as shaly and sandy formation respectively.

\section{Determination of Maximum Flooding Surfaces from Well Logs}

The Maximum Flooding Surfaces (MFSs) were identified as shaliest part of the section. It represents the points with the highest gamma ray values.

\section{Determination of Transgressive Surface from Well Logs}

The Transgressive Surface (TS) is a prominent flooding surface. It represents the first major flooding surface to follow the sequence boundary and is usually identified on the gamma ray log by fining upward. This is an indication of the beginning of rise in relative sea level at an increasing rate.

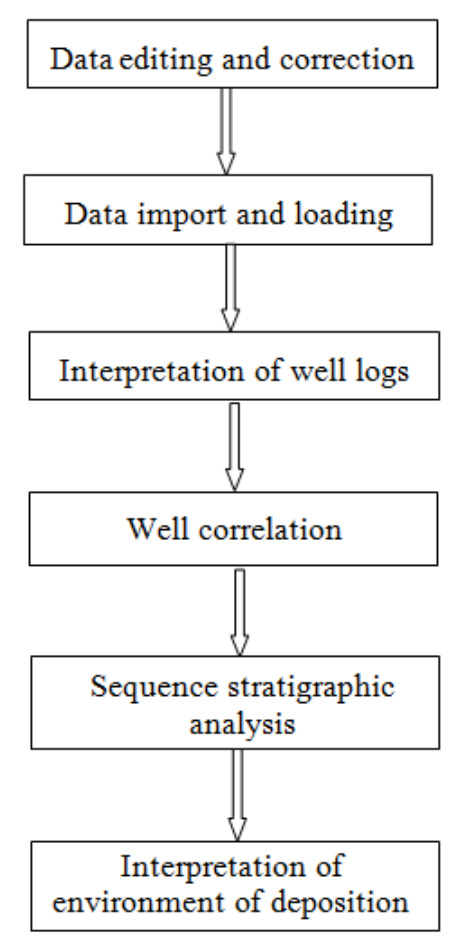

Fig. 3. Flow chart of the research work

$$
\begin{aligned}
& \text { SB II - Sequence Boundary II } \\
& \text { HST - Highstand Systems Tract } \\
& \text { MFS - Maximum Flooding Surface } \\
& \text { TST - Transgressive Systems Tracts } \\
& \text { LST - Lowstand Systems Tracts } \\
& \text { SB I - Sequence Boundary I }
\end{aligned}
$$

Fig. 4. Hierarchy of bounding surfaces

\section{Determination of Depositional Sequence from Well Logs}

Depositional sequence was determined by the cycle of sea level changed. In vertical succession, depositional sequences were identified in the well logs by using the order (Fig. 4).

\section{Determination of Environment of Deposition Using Well Logs}

The environment of deposition was identified using gamma ray $\log$ responses. A funnel $\log$ response (progradational) represents a change from mainly shale into high sand lithology. It also indicates a gradual change from clastic to carbonate deposition. A bell log response is an indication of lithology change from sand to shale (waning of submarine fans-reducing sand contents). 
It is predominant within meandering or tidal channel deposits in a non-marine setting. A cylindrical response indicates fluvial channel sands, turbidites and aeolian sands.

\section{Well Correlation}

Well logs for wells F, A, C, D, B and E were placed side by side and correlated to determine stratigraphic units that are equivalent in time, age or stratigraphic position.

\section{Results}

The qualitative examination of the gamma ray logs indicated presents of sand and shale lithologies which are alternated. The sand and shale lithologies occurred approximately in a ratio of 80:20 in Well C; 70:30 in wells $\mathrm{F}$ and $\mathrm{D}$; 60:40 in wells $\mathrm{A}, \mathrm{B}$ and $\mathrm{E}$. One major lithostratigraphic unit (Agbada Formation) was identified. Applying the principle of sequence stratigraphy interpretation to the Agbada Formation, gamma ray log response that gradually decrease in value and then rapidly increase (gradually coarsen and then abruptly fine) is interpreted to be prograding delta deposits. Those that abruptly decrease in gamma ray value and have "blocky" or gradually increasing trends (abruptly coarsen and remain sandy or gradually fine) are interpreted to be channel deposits.

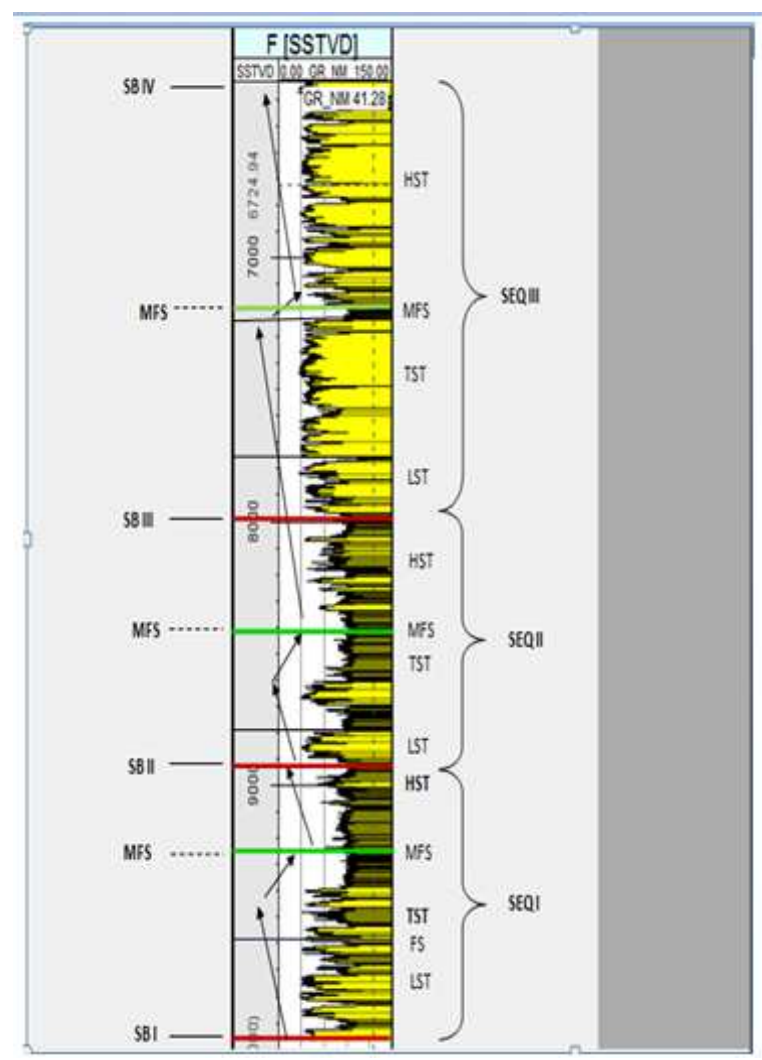

Fig. 5. One dimensional stacking pattern showing delineated candidate bounding surfaces in Well $\mathrm{F}$
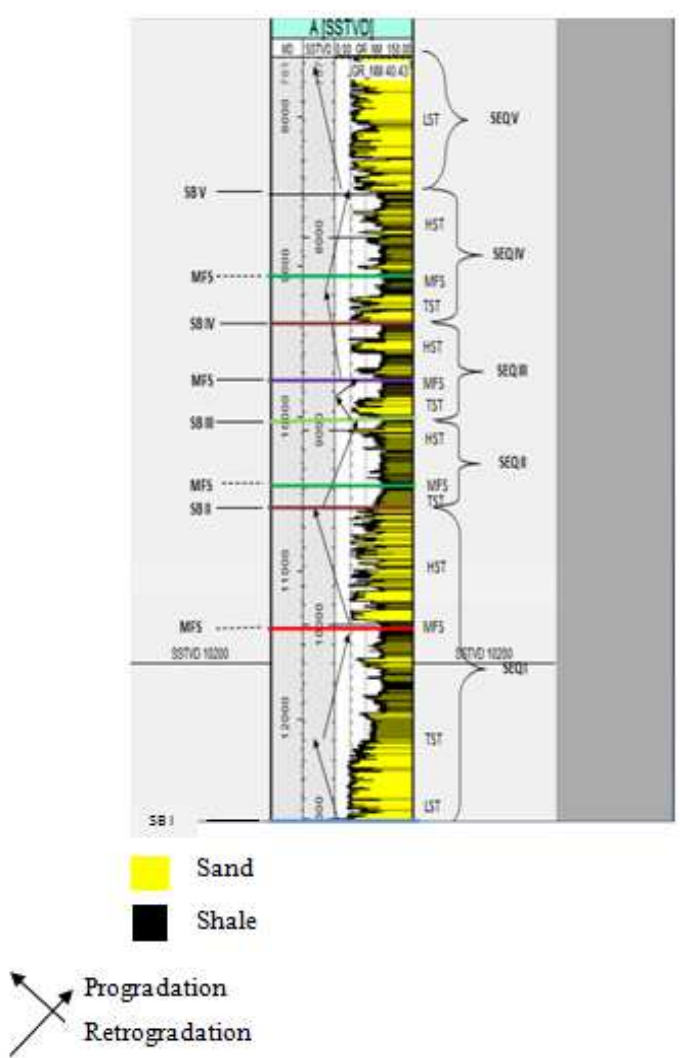

Fig. 6. One Dimensional stacking pattern showing delineated candidate bounding surfaces in Well A

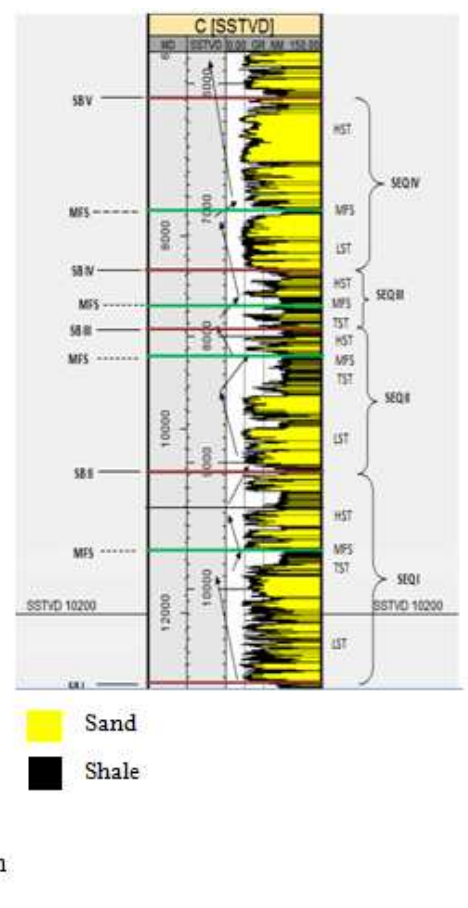

Fig. 7. One dimensional stacking pattern showing delineated candidate bounding surfaces in Well C 

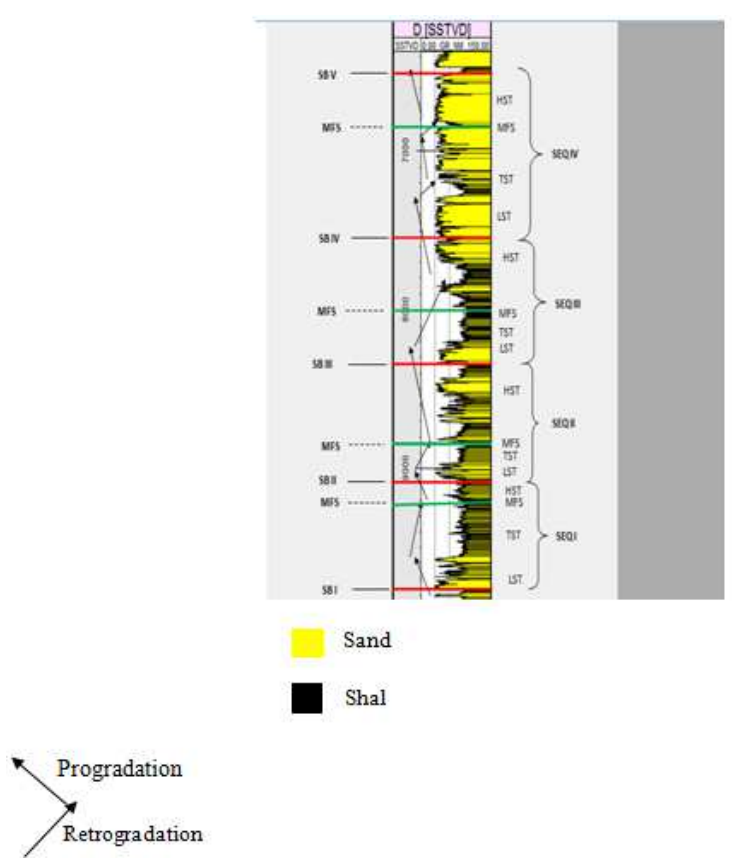

Fig. 8. One Dimensional stacking pattern showing delineated candidate bounding surfaces in Well D
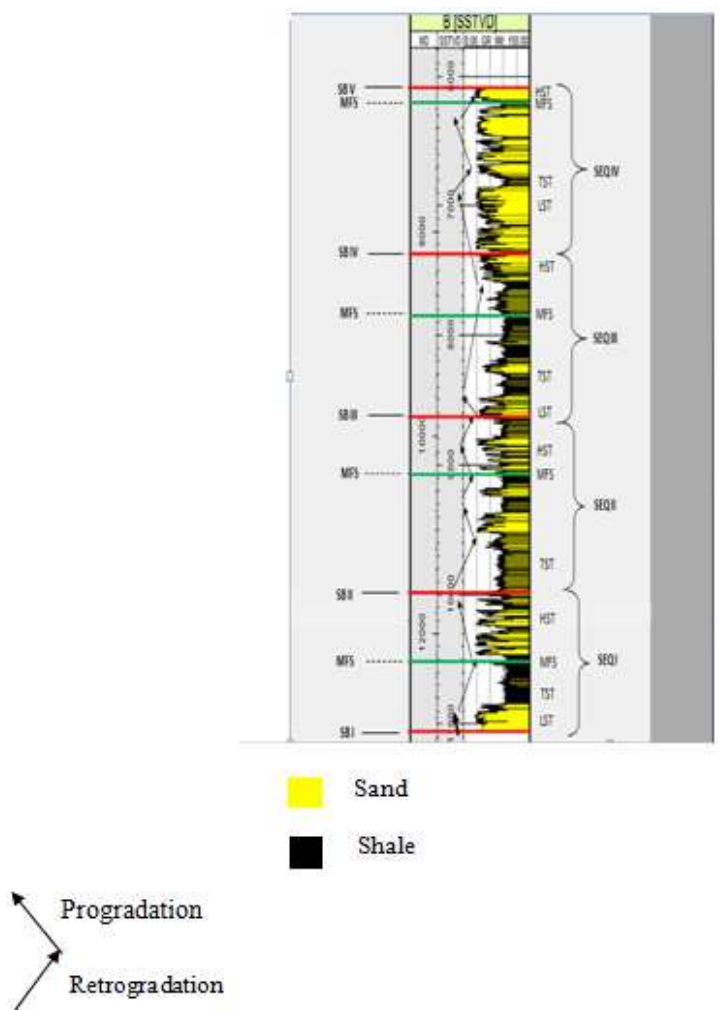

Fig. 9. One dimensional stacking pattern showing delineated

Figure 5-10 show one-Dimensional (1-D) sequence stratigraphy analysis performed on the well logs from wells F, A, C, D, B and E in the study area using vertical stacking patterns of progradation and retrogradation.
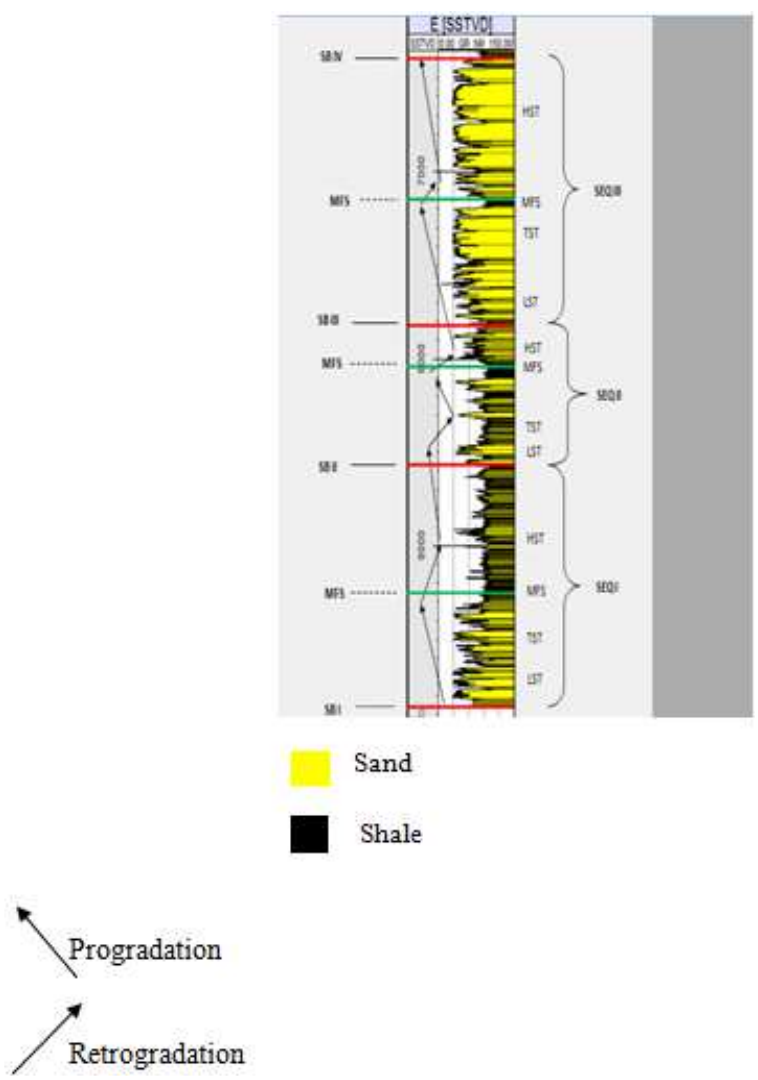

Fig. 10. One dimensional stacking pattern showing delineated candidate bounding surfaces in Well B

Figure 11 shows the correlation panel of well logs used. The Maximum Flooding Surfaces (MFSs) and Sequence Boundaries (SBs) with their ages have been used for the correlation. Six reservoir sands namely sand 1 to sand 6 were identified and delineated in the wells. The tops and bases of the reservoirs were correlated as shown in Fig. 12.

\section{Discussion}

The result of the sequence stratigraphy analysis for the various well is discussed independently as follows;

\section{Sequence Stratigraphy of Well A}

Five sequences have been recognized in this well (Fig. 6).

\section{Sequence I $(11,100-9,400 \mathrm{ft})$}

In this sequence, the $\operatorname{LST}(11,100-10,600 \mathrm{ft})$ is made up of progradational stacking pattern of sand. The TST thinned into a major condensed section the MFS which is mainly made up of shale. The HST $(10,000-$ 9,400 ft) lies directly above the MFS and is made up of mostly sand interbedded by thinned shale. The HST is terminated at the top by the SBII at 9,400 ft. 


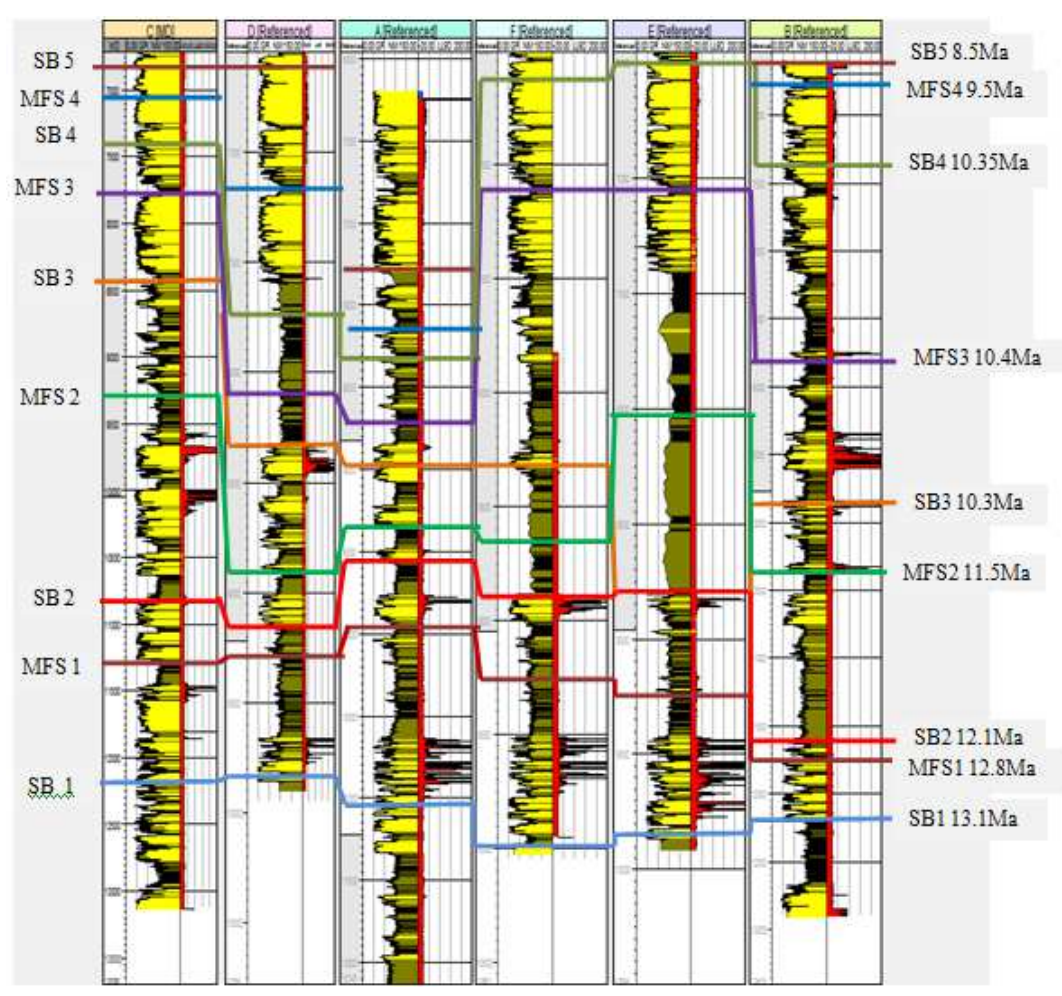

Fig. 11. Correlation of wells showing bounding surfaces with ages

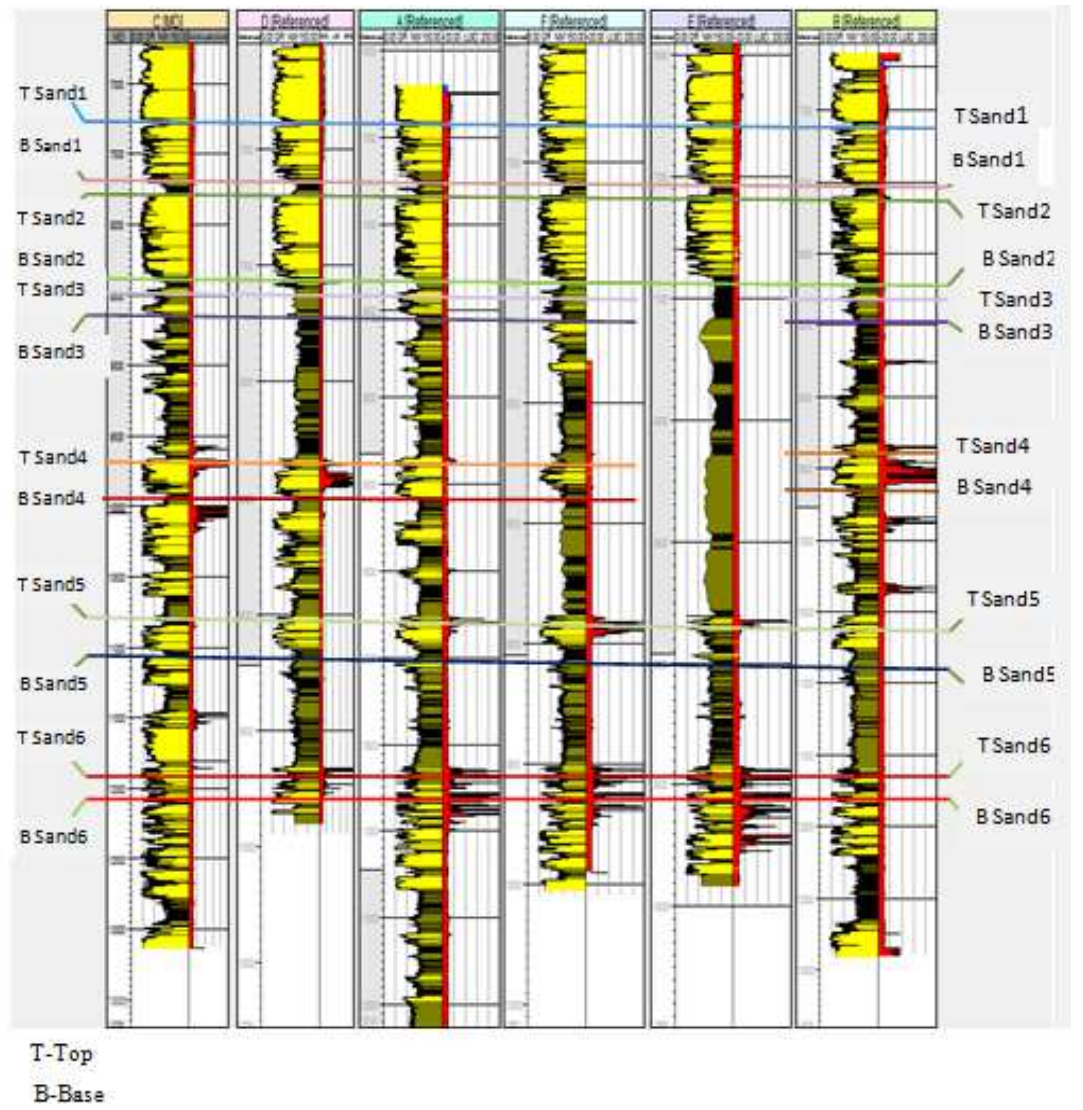

Fig. 12. Correlation of wells showing bounding surfaces with ages 


\section{Sequence II $(9,400-8,950 \mathrm{ft})$}

In this sequence, the LST was not observed. The TST $(9,400-9,300 \mathrm{ft})$ consists of interbedded shale with retrogradational stacking signature. The TST thinned into the MFS which is made up of mainly shale at a depth of 9,300-9,250 ft. The HST $(9,250-8,950 \mathrm{ft})$ Consist of shale/mudstone that changed to sandy mudstone interbedded by fine-medium grained sandstone of approximately $50 \mathrm{~m}$.

\section{Sequence III $(8,950-8,450 \mathrm{ft})$}

The LST was not penetrated in this sequence. The TST $(8,950-8,800 \mathrm{ft})$ is made up of argillaceous sandstone. The stacking pattern is progradational with upward coarsening units. The abrupt change of the well log signature coupled with major condensed section is an indication of MFS $(8,800-8,700 \mathrm{ft})$. The HST $(8,700-8,450 \mathrm{ft})$ is made up of two sandy units interbedded by shale.

\section{Sequence IV $(8,450-7,400 \mathrm{ft})$}

This sequence is made up of the TST, MFS and HST. The LST was not penetrated in this sequence. The TST $(8,450-8,300 \mathrm{ft})$ has coarsening upward progradational stacking signature of sandy units. At the top of the TST at a depth of $8,200 \mathrm{ft}$ is the MFS and it is a shaly condensed section. The HST $(8,200-7,780 \mathrm{ft})$ has two units of sand interbedded by shale The HST is fines up to the top into an erosional truncation (sequence boundary) at the depth of $7,780 \mathrm{ft}$. The HST siltstone changed to coarsening upward pattern of the sandstone unit of the overlying lowstand prograding complex.

\section{Sequence V (7,780-7080 ft)}

This sequence is a lowstand prograding complex. It is made up of continental sand interbedded by sandstones (coarse grained of about $80 \%$ ). lithofacies is typical of Benin Formation. The log pattern is a serrated shaped with coarsening upward stacking pattern.

\section{Sequence Stratigraphy of Well B}

Four sequences have been identified in this Well as shown in Fig. 9. They are Sequence I, II, III and IV.

\section{Sequence I (11,060-10,000 ft)}

This sequence is made up of LST, TST, MFS and HST. This sequence starts at depth $11,060 \mathrm{ft}$ and ends at $10,000 \mathrm{ft}$. The LST begins this Sequence bounded below by SB I. The sand package above the boundary is described as a prograding complex showing a coarsening upward pattern. The LST is overlain by the TST that covers the depth of 10,900-10,700 ft and consists of an overall retrograding parasequence stacking pattern capped by MFS at the depth of 10,500 ft. The HST rests on the MFS and covers the depth range of 10,500-10,000 ft. It has a progradational stacking pattern that coarsens upward and truncates at the top by SB II.

\section{Sequence II (10,000-8,640 ft)}

Sequence II consists of TST, MFS and HST. The TST extends from the depth of $10,000-9,200 \mathrm{ft}$. This portion of the subsurface is found to exhibit individual parasequence patterns aggrading in the beginning, coarsening up in the middle and later fines upward. The TST is capped by the MFS at the depth of $9,150 \mathrm{ft}$ associated with a major condensed section.

This sequence is terminated by the HST which startsat depth $9,080 \mathrm{ft}$ showing some initial progradational stacking pattern and later aggraded to be terminated at the SBII.

\section{Sequence III (8,640-7,400 ft)}

The whole sequence covers a total depth of 8,640$7,400 \mathrm{ft}$ and bounded at the base by the SB II. It begins with the LST $(8,640-8,500 \mathrm{ft})$ having prograding sand units. The TST $(8,500-8,200 \mathrm{ft})$ has an overall retrogradational stacking pattern. The lower sandy unit fines upward into a condensed section of shale unit forming the MFS at the depth of 7,850ft. The HST starts with a prograding stacking pattern of sandy unit interbedded with thin shale intercalations.

\section{Sequence IV (7,400-6,100 ft)}

Resting upon the SB III is the uppermost sequence encountered in this Well. It is made up of LST, TST, MFS and HST. The LST (7,400-6,850 ft) is made up of about $85 \%$ sand indicating the presence of potential reservoir rock. It has an overall prograding stacking pattern which coarsens upward from the base of SB III. The TST is made up of fining upward retrogradational stacking pattern of sandy units interbedded by thinly bedded shales. The MFS is defined at the top of the TST at depth of $6200 \mathrm{ft}$ with shaly condensed section. The HST marks the end of this sequence with a thin prograded sandy unit.

\section{Sequence Stratigraphy of Well C}

Four sequences have been recognized in this Well (Fig. 7).

\section{Sequence I $(10,700-9,100 \mathrm{ft})$}

The sequence is made up of LST, TST, MFS and HST. The LST $(10,700-9,900 \mathrm{ft})$ has progradational stacking pattern and is made up of mostly sandy units. The Low stand prograding complex has coarsening upward stacking pattern. The TST $(9,900-9,850 \mathrm{ft})$ is made up of fining upward retrogradational stacking pattern of shale units interbedded by thinly bedded sands. The MFS at the top of the transgressive systems tract at depth of $9,700 \mathrm{ft}$ is also a shaly condensed 
section. The HST $(9,700-9,100 \mathrm{ft})$ is made up of several sandy units interbedded by thinly bedded shale intercalations. The HST is dominantly made up of progradational stacking pattern of sandy units.

\section{Sequence II $(9,100-7,930 \mathrm{ft})$} HST.

This sequence is made up of LST, TST, MFS and

The LST (9100-8500 ft) has a prograding stacking pattern and is made up of mostly sandy units which coarse upward. The TST $(8,500-8,200 \mathrm{ft})$ has an overall retrogradational stacking pattern. The lower sandy unit fines upward into a condensed section of shale unit forming the Maximum Flooding Surface (MFS) at the depth of $8,170 \mathrm{ft}$. The HST is made up of a single unit of argillaceous sandstone bounded at top and base by shales. The well log signature shows a fining upward stacking pattern. There is an abrupt change at the point of inflection that defines the Sequence Boundary (SB).

\section{Sequence III (7,930-7,480 ft)}

The sequence is made up of TST, MFS and HST. The TST $(7,930-7,800 \mathrm{ft})$ is composed mainly of shales, which fines upward in a retrogradational stacking pattern. The TST is capped by MFS at depth of 7,800$7,700 \mathrm{ft}$. The maximum flooding surface consists of condensed shale units. The HST $(7,700-7,480 \mathrm{ft})$ is composed mainly of sandy unit and has fining upward stacking pattern.

\section{Sequence IV (7,480-6,100 ft)}

This sequence consists of LST, MFS and HST. The LST (7,480-6,900 ft) has progradational stacking pattern which coarsens upward and is made up of mainly sandy unit. The MFS at the depth of 7,000 ft consists of shaly condensed section which fines upward. The HST (7,000-6,100 ft) consists of two sand units and thin interbedded shale units. It also has a coarsening upward stacking pattern.

\section{Sequence Stratigraphy of Well D}

Four sequences have been observed in well D. They include Sequence I, II, III and IV (Fig. 8).

\section{Sequence I $(9,760-9,100 \mathrm{ft})$}

The sequence consists of LST, TST, MFS and HST. The LST $(9,760-9,580 \mathrm{ft})$ has progradational stacking pattern and is made up of mostly sandy units interbedded with thin shale intercalations. The Lowstand prograding complex has coarsening upward stacking pattern. The sandy unit in the TST fines upward and gradually changed into shaly condensed section defining the MFS at depth of 9,220 ft. The HST $(9,220-9,100 \mathrm{ft})$ is made up of progradational stacking pattern that coarsens upward to the SB $(9,100 \mathrm{ft})$.

\section{Sequence II $(9,100-8,350 \mathrm{ft})$}

Sequence II is the same as I. It lies conformably on sequence I. The LST $(9,100-8,980 \mathrm{ft})$ is made up of sand which is progradational. The TST $(8,980-8,850 \mathrm{ft})$ has retrogradational stacking pattern and thinned into the MFS at a depth of $8,850 \mathrm{ft}$. The shale/mudstone of the HST prograde into siltstone and subsequently to sandy units.

\section{Sequence III $(8,350-7,550 \mathrm{ft})$}

This sequence consists of the same system tracts as in II. The LST $(8,350-8200 \mathrm{ft})$ lies immediately above the SB III. It has two sand units. It has progradational stacking pattern that coarsens upward into the TST. The TST has a retrogradational stacking pattern that fines upward into the shaly condensed section defining the MFS (8,100-7,980 ft). The HST $(7,980-7,550 \mathrm{ft})$ lies directly above the MFS and has a progradational stacking pattern that coarsens upward to the SB IV.

\section{Sequence IV (7,550-6,500 ft)}

Sequence IV has the same sequence as III. The LST is present as lowstand prograding complex at the depth interval of 7,550-7,300 ft. The TST $(7,300-6,850 \mathrm{ft})$ is composed of mostly sand units with thin shale intercalations. The Transgressive Systems Tract fines upward in a retrogradational stacking signature. At a depth of $6,850 \mathrm{ft}$, it is capped by MFS. The HST $(6,850-$ $6,500 \mathrm{ft}$ ) has four units of sand and progradational stacking pattern.

\section{Sequence Stratigraphy of Well E}

This Well comprised of three sequences namely Sequence I, II and III (Fig. 10).

\section{Sequence I $(9,850-8,560 \mathrm{ft})$}

This sequence has LST, TST, MFS and HST. The LST $(9,850 \mathrm{~m}-9,650 \mathrm{ft})$ is made up of three sandy units and has coarsening upward stacking pattern. The TST is made up of several sandy units interbedded by thin shale intercalations. The upper section fines gradually upward and changed into shaly condensed section at 9,250 ft.

The HST began with aggradational stacking pattern and finally coarsens upward. The HST consists of sandy units with shale intercalations.

\section{Sequence II $(8,560-7,820 \mathrm{ft})$}

Sequence II lies conformably on sequence I. The base of sequence II $(8,560 \mathrm{ft})$ coincides with the top of sequence I. The lower part of this stratigraphic interval $(8,560-8,450 \mathrm{ft})$ is characterized by LST prograding complex. The top is a transition into overlying TST. Four retrogradational sandy units made up the TST. The TST is capped by the condensed section of MFS at the depth of $8,100 \mathrm{ft}$. The HST $(8,000-7,820 \mathrm{ft})$ is made up 
of progradational stacking pattern of several sandy units with interbedded shale intercalations.

\section{Sequence III (7,820-6,400 ft)}

This sequence lies immediately above sequence II. It began with the LST which progrades upward from the base of sequence II. It is made up of five sandy units separated by thin shaly intercalations. Four units of sands (7,500-7,200 $\mathrm{ft}$ thickness) made up the TST overlain by shales. This shale formed a seal over the sand reservoir. The MFS which is the condensed section at the depth of 7,150 ft capped the TST. Seven sandy units made up the HST. The lower earlier units, at depths of 7,150-7,000 $\mathrm{ft}$ have progradational stacking pattern which coarse upward. The upper units have progradational stacking pattern and is capped by shaly unit that fines into the erosional truncation defined by the SB at depth of $6,400 \mathrm{ft}$.

\section{Sequence Stratigraphy of Well F}

Three stratigraphic sequences were observed in well F. They are Sequence I, II and III (Fig. 5).

\section{Sequence I $(10,000-8,920 \mathrm{ft})$}

The sequence started with a progradational sandy unit which changed to a retrogradational shale/mudstone unit. This unit is made up of Lowstand Systems Tract, Transgressive Systems Tract and Highstand Systems Tract. The LST lies between the depth of 10,000 ft at the base of the log where the analysis commenced and 9600 $\mathrm{ft}$. The top of the LST is marked by flooding surface associated with low gamma ray value.

The Transgressive Systems Tract (TST) within the depth interval $(9,600-9,400 \mathrm{ft})$ overlies the thickly bedded LST. The TST $(9,400 \mathrm{ft})$ is marked at the top by the identification of the high gamma ray values, which is suggestive of a possible source rock and highly fossiliferous of calcareous fossils [10]. The base is defined by flooding surface, hemapelagic in nature and shifting downward into turbidite sand.

The Highstand Systems Tract (HST) of interval (9250$8920 \mathrm{ft})$ marks the top of sequence I. The top of the interval at $((8,950-8,920 \mathrm{ft})$ is marked by a condensed section rich inorganic matter. The interval is further characterized by coarsening and shallowing upward sequence of intercalating shale and sandstone units.

\section{Sequence II $(8,920-8,000 \mathrm{ft})$}

Sequence II lies conformably on sequence I. The base of sequence II $(8,920 \mathrm{ft})$ coincided with the top of sequence I. The lower part of this stratigraphic interval $(8,920-8,800 \mathrm{ft})$ is characterized by LST prograding complex. The top is a transition from upward shallowing to upward deepening into overlying TST. The interval is characterized by the upward coarsening sands deposited in the shoreface and grades into deeper hemapelagic shale. The Transgressive Systems Tract (TST) overlies the LST. The TST is wedge-like in nature because it is cyclical interms of sediments packaging pattern. The top of the interval placed at $(8,420 \mathrm{ft})$ is marked by MFS defined by high gamma ray value. The MFS indicates maximum shoreline shift into the continent during transgression. The HST located at $(8,200 \mathrm{ft})$ overlies the MFS. The top of the interval is characterized by flooding surface. There are sediment aggradations and the interval shows coarsening and shallowing upward and shale interbeds.

\section{Sequence III (8,000-6,300 ft)}

It lies on Sequence II which indicates that the base of Sequence III coincides with the top of Sequence II $(8,000 \mathrm{ft})$. This sequence is made up of about $80 \%$ sand indicating the presence of potential reservoir rock. The LST $(8,000-7,860 \mathrm{ft})$ and TST $(7,860-7,440 \mathrm{ft})$ are made up of units of sandstones interbedded by thinly bedded shales. The sandstone units are individually progradational with coarsening upward stacking pattern towards the MFS at the depth of $7400 \mathrm{ft}$. The HST (7,380-6,300 ft) consists of five sandy units interbedded by bedded shale. The HST is dominantly made up of progradational stacking pattern of sandy units.

\section{Sequence Stratigraphy Interpretation}

Type-1 depositional sequence was observed in the wells. The sequence is made up of Lowstand prograding complex. The stratigraphic column in the wells E and F have three sequences; SEQ I, II and III. Wells B, C and D have four depositional sequences (SEQ I, II, III and IV) while well A has five depositional sequences. The sequence stratigraphic interpretation for the wells are shown in Fig. 5 to 10.

The depth penetrated by well $\mathrm{F}$ and $\mathrm{E}$ are 10,000$9850 \mathrm{ft}$ respectively. Three maximum flooding surface and depositional sequences were delineated. The sequences are; SEQ I, from 10,000 to $8,920 \mathrm{ft}$, SEQ II from 8920 to $8000 \mathrm{ft}$ and SEQ III from 8000 to $6300 \mathrm{ft}$ as shown in Fig. 5. Well A was logged from the depth of 7,080 to $11,100 \mathrm{ft}$. Four MFS were recognized in the gamma ray log at the depths of 10,050, 9,280, 8,740 and $8,200 \mathrm{ft}$, Similarly, five depositional sequences were also identified, comprising of SEQ I, which ranges from 11100 to $9400 \mathrm{ft}$, SEQ II, from 9400 to $8950 \mathrm{ft}$, SEQ III, from 8950 to $8,450 \mathrm{ft}$, SEQ IV, from 8450 to $7400 \mathrm{ft}$ and SEQ V, from 7400 to $7080 \mathrm{ft}$ (Fig. 6).

Well B (Fig. 9) penetrated depth of about $11,060 \mathrm{ft}$ but was logged from $6,100 \mathrm{ft}$. This well had three MFSs at a depth of 10500, 9150 and $7850 \mathrm{ft}$ respectively. Similarly, four depositional sequences were identified. These include SEQ I, from 11060-10,000 ft, SEQ II, from 10000-8640 ft, SEQ III, from 8640-7,400 ft and SEQ IV, from 7400-6100 ft respectively. 
The stratigraphic column in well $\mathrm{C}$ was divided into four depositional sequences and four MFS as shown in Fig. 7. This well penetrated total depth of $10,700 \mathrm{ft}$ while the logging started at a depth of $6100 \mathrm{ft}$. The MFSs I, II, III and IV were recognized at the depth of 9,700, 8,170, 7760 and $7,000 \mathrm{ft}$ respectively. Four depositional sequences were also identified as follows: SEQ I, 10700 -9 $100 \mathrm{ft}$, SEQ II, 9100-7,930 ft, SEQ III, 7930-7480 ft and SEQ IV, 7480-6,100 ft.

The depth penetrated by well D (Fig. 8) is $9760 \mathrm{ft}$ and the logging started from the depth of $6500 \mathrm{ft}$. Four MFSs at 9220, 8850, 8000-7250 ft and $6500 \mathrm{ft}$ were delineated. Similarly, four depositional sequences were also identified namely; SEQ I, from 9760 to $9100 \mathrm{ft}$, SEQ II, from 9100 to $8350 \mathrm{ft}$, SEQ III, from 8350 to $7550 \mathrm{ft}$ and SEQ IV, from 7550 to $6500 \mathrm{ft}$.

\section{Interpretation of Environment of Deposition}

The environment of deposition of the reservoir sands were inferred based on $\log$ characteristics and log motifs. The sediments associated with the LST in the studied wells occurred as low stand prograding wedges at or near the shelf margin and rising slowly enough for sedimentation to keep pace with shelf-edge deltaic process.

At the upper boundary of the LST is an erosional surface representing initial marine incursion landward within the TST. This was identified in all the wells as an initial deepening signature of a typical sub-tidal channel environment. The constant deepening interval above the LST depicts a typical proximal lagoon setting that grades into a sub-tidal environment with an overall prograding gamma ray signature. During the HST, the sea-level rises decreased and are characterized by initially aggradational deep sea shales that grade into intervals of shallowing upwards. The sands at the top of the HST prograde spatially into shales. This prograding highstand complex corresponds to the shoreface depositional environment. The shoreface sands of the HSTare usuallyassociated with good reservoir properties such as porosity and permeability.

With reference to Fig. 11 and 12, the key bounding surfaces MFSs and SBs were used for the well correlation. The six wells were placed side by side from each other and their common features were correlated. With respect to the shapes of the log motifs, the upper part of the logged section of the wells is made up of mostly sand units with prograding stacking pattern having thin intercalating shales. This is common to all the six wells indicating lateral continuity of the reservoir sand in all the wells. This was closely followed by condensed section (Maximum flooding surface) of shales with thin sand interbeds.

\section{Conclusion}

Sequence stratigraphic analysis has been carried out and the result used to examine hydrocarbon potential.
The result was based on well log shapes within a chronostratigraphic framework of the field. The sand and shale lithologies observed in the ray logs occurred approximately in a ratio of 80:20 in Well $\mathrm{C}$; 70:30 in wells $\mathrm{F}$ and $\mathrm{D} ; 60: 40$ in wells $\mathrm{A}, \mathrm{B}$ and $\mathrm{E}$ within the logged intervals.

Two bounding surfaces have been identified in the study area. Five sequence boundaries occur in in wells $\mathrm{A}, \mathrm{B}, \mathrm{C}$ and $\mathrm{D}$ respectively and four in wells $\mathrm{E}$ and $\mathrm{F}$. Similarly, four maximum flooding surfaces were observed in wells A, B, C and D while three occur in wells $\mathrm{E}$ and $\mathrm{F}$ respectively.

Furthermore, four depositional sequences were also identified in wells $\mathrm{A}, \mathrm{B}, \mathrm{C}$ and $\mathrm{D}$ while three depositional sequences were observed in wells $\mathrm{E}$ and $\mathrm{F}$. The four recognized maximum flooding surfaces occurred at approximate depths of 11300, 9300, 9750 and $7,050 \mathrm{ft}$ while the five sequence boundaries were recognized at the depths of $12150,10850,8550,7425$ and $6875 \mathrm{ft}$ respectively. Therefore, high quality geophysical logs and sequence stratigraphy can be used efficiently for oil and gas exploration.

\section{Acknowledgement}

Thanks to the Department of Petroleum Resources (DPR) and Shell Petroleum Development Company (SPDC) for making the data available.

\section{Funding Information}

There was no external financial support for the project research.

\section{Author's Contributions}

Alphonsus Joseph Eyo: Carried out MSc research work from which the paper was extracted. He analyzed and interpreted the data. He also prepared the manuscript.

Godwin Omokenu Emujakporue: Designed and supervised the research work. He also read and edited the manuscript.

\section{Ethics}

This article is original and contains unpublished material. The authors read and approved the manuscript. No ethical issues and conflict of interest.

\section{References}

Ekweozor, C.M. and E.M. Daukoru, 1994. Northern Delta Depobelt Portion of the Akata-Agbada Petroleum System, Niger Delta, Nigeria. In: The Petroleum System-From Source to Trap, Magoon, L.B. and W.G. Dow (Eds.), American Association of Petroleum Geologists Memoir 60: Tulsa, American Association of Petroleum Geologists Bulletin, pp: 599-614. 
Embry, A., E. Johannessen, D. Owen, B. Beauchamp and P. Gianolla, 2007. Sequence stratigraphy as a "concrete" stratigraphic discipline. Report of the ISSC Task Group on Sequence Stratigraphy, Calgary.

Knox, G.J. and M.E. Omatsola, 1988. Development of the Cenozoic Niger Delta in terms of the Escalator regression Model and Impact on Hydrocarbon Distribution. In: Coastal Lowlands: Geology and Geotechnology, Van der Linden, S.A.P.L. Cloetingh, J.P.K. Kaasschieter, W.J.E. van de Graaff and J. Vandenberghe et al., (Eds.), Dordrecht Klumer Academic Publishers, pp: 181-202.

Ola-Buraimo, A.O., J.E. Ogale and O.F. Adebayo, 2010. Well-log sequence stratigraphy and paleobathymetry of well-X, offshore western Niger Delta, Nigeria. World Applied Sci. J., 10: 330-336.

Orife, J.M. and A.A. Avbovbo, 1994. Stratigraphic and unconformity traps in the Niger Delta. Am. Assoc. Petroleum Geol. Bull., 66: 251-262.
Oyedele, K.F., D.O. Ogagarue and D.U. Mohammed, 2013. Integration of 3D seismic and well log data in the optimal reservoir characterization of EMI field, offshore Niger Delta oil province, Niogeria. Am. J. Scientific Indust. Res., 4: 11-21. DOI: 10.5251/ajsir.2013.4.1.11.21

Petroconsultants, 1996. Petroleum Exploration and Production database. Texas Petroconsultants, Inc., Houston.

Reijers, T.J.A., S.W. Petters and C.S. Nwajide, 1997. The Niger Delta Basin. In: African BasinsSedimentary Basin of the World 3, Selley, R.C. (Ed.), Elsevier Science, Amsterdam, pp: 151-172.

Tuttle, M.L.W., R.R. Charpentier and M.E. Brownfield, 1999. The Niger Delta petroleum system: Niger Delta province. Nigeria, Cameroun and Equatorial Guinea, Africa: USGS Open-file Report 99-50-H.

Whiteman, A.J., 1982. Nigeria, its Petroleum Geology, Resources and Potential. 1st Edn., Graham and Trotman, London, ISBN-10: 0860102645, pp: 394. 